\title{
Eco-Fishing Port Assessment Model as an Environmental Management Tool on Coastal Fishing Port 'Pondokdadap' - Indonesia
}

\author{
Achmad Wicaksono, Bagyo Yanuwiadi, and Agus Dwiyanto
}

\begin{abstract}
To manage fishery resources in Indonesia with the principle of sustainability, it is necessary to apply the ecofishing port concept. This study aims to develop a model for assessment of eco-fishing port with prevailing conditions and regulations in Indonesia. From the model that prepare, the application on Coastal Fishing Port (PPP) Pondokdadap has result value of the eco-fishing port is 67 , with details of ecological indicator value 58, fishing indicator value 69 and port indicator value 76 . The value indicates that $P P P$ Pondokdadap has not met the criteria of eco-fishing port conformity (value 80-100) and in the process of applying the fishing port management principle of environmentally friendly. The non-fulfillment of these criteria is due to the environmental regulations not implemented properly, or the level of compliance under $100 \%$. From the indicators obtained a fishing port environmental management index (FEMI) this study developing a model of eco-fishing port management, which use as a tool to check the fishing port environmental management development. Increased FEMI values will show that improvements in ecological, fishing, and port indicators to fulfill eco-fishing port assessment standards.
\end{abstract}

Index Terms - eco-fishing port, environmental management, indicator, PPP Pondokdadap.

\section{INTRODUCTION}

$\mathbf{F}$ ishing Port in Indonesia has economic and government functions, with activities consisting of a ship docked, storing and processing facilities for fishery products and related fishery activities [1]. Coastal Fishing Port (PPP) Pondokdadap is producing the best handline tuna in Indonesia and has the potential of fishery products for domestic and export [2]. However, the potential of this fishery needs to get special attention in the management so fisheries resources remain sustainable. This step needs according to research on Catch Per Unit Effort (CPUE) 2013-2015 in PPP Pondokdadap which shows decreasing result of more than $25 \%$ in 1 year, and show that the use of tuna is overfishing [3]. In managing the potential of

A. Wicaksono is with the Department of Civil Engineering, Brawijaya University, Malang, East Java, Indonesia (e-mail: agus2yanto@gmail.com)

B. Yanuwiadi is with the Department of Biology, Brawijaya University, Malang, East Java, Indonesia

A. Dwiyanto is with the Post Graduate School of Environmental and Development, Brawijaya University, Indonesia. fisheries, the Ministry of Marine Affairs and Fisheries (MMAF) implemented a food security guarantee program throughout the production chain to support and improve fishery products quality. This step pursued by applying a good fishing port management fishery and environmental resources use [4]. Port management links to the role of ports that support regional economic development through goods distribution from the supply side of port facilities and infrastructure [5]. Environmental friendly port infrastructure development includes the implementation methods and materials used, and the wastewater treatment facility is the key to port environmental management in the preoperational stage [6].

The ports and their activities are very vulnerable in causing environmental damage, to overcome this condition the port must have good and measurable environmental management [7]. The international issue states that the environmental impacts of port activities and maritime activities are increasing. Therefore, it is necessary to manage ports, especially small-scale ports. To carry out the program, need a tool to manage environmental impacts by applying environmental management principles [8]. The main aspect of port environmental management in addressing environmental concerns is regulatory compliance. This base on the first step of the environmental management system being implemented is the policies formula in providing protection to the port environment [9]. To support policies and regulations implementation, need a tool of a port environment with science-based management, systematic, and proper approaches [10].

Tools and methods of environmental monitoring have been developed, one of which is Environmental Performance Indicators (EPI) for port operational monitoring (eg. noise, dust, energy consumption, and dredging), port management (service and compliance), and environmental conditions (eg. water, air, and sediment) [11]. In addition, ports in European countries have also developed tools that help port authorities in assessing significant aspects and levels of environmental management of ports [10]. In terms of environmental management, the main components implemented by most ports in Europe are environmental managers appointment, the formulation of environmental policies, and environmental monitoring activities [12]. In addition, environmental management carries out by implementing ISO 14001. Implementation of ISO 14001 on ports will cut the risk of negative environmental impacts of ports, improve fishery products 
quality, increase export potential of fishery products and improve environmental conditions of fishing ports [13]. Referring to the concept of eco-port used in Europe, fishing ports in Indonesia require adjustments to apply this concept. This is due to differences in characteristics, types of commodities, and port managers in Indonesia. Even though different of the condition, the key to port environmental management is the port authority must be committed and actively realize sustainable development in plan and action [14].

With the above conditions, it is necessary to develop the eco-fishing port model in Indonesia. Since port management on the environmental issue is heavily dependent on prevailing policies and regulations taking into account the economic, commodity, geographical, cultural, characteristic, and local community backgrounds [7]. Development of the eco-fishing port model bases on environmental indicators of fishing port and regulation on the port, environment, health, and fishery activities. This condition is under the Indonesian National of Standard on the Environmental Management System, which explains that the management of an organization must take into account the requirements of legislation and other provisions related to the environment [15]. The purpose of this research is to develop eco-fishing port assessment model in Indonesia, indicators, and index of environmental management in accordance with the fishing port condition in Indonesia that can be used as an environmental management tool.

\section{MethOD}

The research on the eco-fishing port assessment model as an environmental management tool on PPP Pondokdadap used a quantitative approach. This research was conducted from January to April 2018. There are six steps taken in this study, namely: 1) Eco-port and fishing port literature study, 2) Environmental regulation collection and review, 3) Data collection related to the environmental activities, impacts, and aspects of the fishing port by survey, 4) Eco-fishing port assessment model preparation, 5) Determining ecofishing port assessment model, and 6) Apply and compare assessment results with European standards.

Assessment model use matrix and questionnaire forms that adjusted to the condition and regulation of fishing ports in Indonesia (Fig. 1 and Table V). The eco-fishing port assessment model matrix and questionnaires fulfillment was addressed to the PPP Pondokdadap managers, Fisheries Supervisors, and Non-Government Organizations through interviews and data comparison of literature and survey results. The questionnaire fulfillment and interviews were only conducted by the respondents who were directly engaged in the fishing port environment management.

\section{Result AND Discussion}

In preparing an eco-fishing port model in Indonesia, an appropriateness of approaches between environmental management system standards (ISO 14001) for environmental regulations and policies is adapt. This is because the environmental management system has become one of the main tools used by companies to discuss environmental aspects and the impact of their activities on the environment [16]. With an environmental management, activities that occur can control not to pollute the environment and conserve natural resources [17].

\section{A. Identification of fishing port manager}

Fishing ports in Indonesia are almost entirely managed by the government, both central and local governments. Data from the Directorate General of Capture fishery MMAF shows that only 2 fishing ports managed by private parties from a total of 816 fishing ports in Indonesia [18]. This condition indicates that the government as the primary stakeholder and the main authority of fishing port management in terms of policy determination, authority control, priority setting and condition [9].

TABLE I

THE CONDITION OF FISHING PORTS IN INDONESIA

\begin{tabular}{lcccccc}
\hline Port Status & \multicolumn{4}{c}{$\begin{array}{c}\text { Fishing Port } \\
\text { Classification }\end{array}$} & Private & Amount \\
\cline { 2 - 5 } & PPS & PPN & PPP & PPI & & \\
\hline Operated & 6 & 14 & 44 & 581 & 2 & 647 \\
\hline $\begin{array}{l}\text { in } \\
\text { Preparation }\end{array}$ & & & & 127 & & 127 \\
\hline not Active & & & 1 & 41 & & 42 \\
\hline Total & 6 & 14 & 45 & 749 & 2 & 816 \\
\hline
\end{tabular}

Source: Strategic Plan of Directorate General of Capture Fisheries 20152019

Pondokdadap categorized as Coastal Fishing Port (Class C Fishing Port) and able to serve the vessel up to the size of 48 GT and become a fisheries business center in the southern region of East Java. PPP Pondokdadap located in Sendangbiru Sub Village, Tambakrejo Village, Malang Regency - East Java, that managed by the Government of East Java Province.

\section{B. Preparation of eco-fishing port assessment model}

The preparation of eco-fishing port model is in line with the applicable port environmental regulations in Indonesia, with the procedures taken are 1) determination of indicators, 2) regulation collection and review, and 3) preparation of the model and assessment.

\section{Determination of indicator}

The main indicators used as a reference in the fishing port management of environmentally friendly are ecological indicators (eco), fishing activities (fishing) and port management (port).

TABLE II

DETERMINATION OF THE MAIN INDICATORS OF ECO-FISHING PORT MANAGEMENT

\begin{tabular}{llc}
\multicolumn{1}{c}{ Ecology Indicator } & Fishing Indicator & Port Indicator \\
\hline $\begin{array}{l}\text { Environmental } \\
\text { documents }\end{array}$ & Fishing and processing & Port facilities \\
\hline $\begin{array}{l}\text { Environmental } \\
\text { monitoring }\end{array}$ & Vessels & Port management \\
\hline \multicolumn{1}{l}{ Source: Analysi resutt $(2018)$} & \\
\hline
\end{tabular}

Source: Analysis result (2018) 
2. Environmental regulation collection and review

Regulations in Indonesia that related with the environment inventories based on components to environmental management of fishing ports. From the inventory will be known regulations that discuss the ecological, fishing, and port indicators then arranged in the form of a matrix in Table III.

TABLE III

A MATRIX OF INDICATORS AND COMPLIANCE OF RULES FOR ECO-FISHING PORT ASSESSMENT MODEL

\begin{tabular}{|c|c|c|}
\hline No & Indicator & Regulation \\
\hline A & Ecology & \\
\hline 1 & $\begin{array}{l}\text { Pollution control } \\
\text { Waste management }\end{array}$ & Minister of Environmental Decree (MED) Number 3 of 2014 \\
\hline 2 & $\begin{array}{l}\text { Environmental management documents } \\
\text { (Environmental Impact Assessment) }\end{array}$ & MED Number 05 of 2012 \\
\hline 3 & Environmental permit document & $\begin{array}{l}\text { Government Regulation of the Republic of Indonesia Number } 27 \\
\text { of } 2012\end{array}$ \\
\hline 4 & Suitability of spatial and regional plans & $\begin{array}{l}\text { Government Regulation of the Republic of Indonesia Number } 26 \\
\text { of } 2008\end{array}$ \\
\hline 5 & Suitability of masterplan & $\begin{array}{l}\text { Minister of Marine and Fisheries Decree (MMAFD) Number } \\
\text { 45/KEPMEN-KP/2014 }\end{array}$ \\
\hline 6 & $\begin{array}{l}\text { Water quality monitoring } \\
\text { Water pollution index activity }\end{array}$ & $\begin{array}{l}\text { MED Number } 115 \text { of } 2003 \\
\text { MED Number } 51 \text { of } 2004\end{array}$ \\
\hline 7 & $\begin{array}{l}\text { Air quality monitoring } \\
\text { Air pollution index activity }\end{array}$ & $\begin{array}{l}\text { MED Number KEP-45/MENLH/10/1997 } \\
\text { Bappedal Decree Number KEP-107/KABAPEDAL/11/1997 }\end{array}$ \\
\hline 8 & Cleanliness of area monitoring & $\begin{array}{l}\text { Law number } 18 \text { of } 2008 \text { (garbage management) } \\
\text { MED Number } 01 \text { of } 2013\end{array}$ \\
\hline 9 & Green Open Space monitoring & $\begin{array}{l}\text { Minister of Public Work Decree Number 05/PRT/M/2008 } \\
\text { MED Number } 01 \text { of } 2013\end{array}$ \\
\hline 10 & Fisherman monitoring & $\begin{array}{l}\text { Government Regulation Number } 33 \text { of } 2013 \\
\text { East Java Government Regulation Number } 3 \text { of } 2016\end{array}$ \\
\hline 11 & Ship waste management & MED Number 05 of 2009 \\
\hline 12 & Port development & Law number 1 of 2014 \\
\hline 13 & Energy consumption & Minister of Transportation Decree Number KP. 201 of 2013 \\
\hline 14 & Pollution controlling and prevention & Law number 32 of 2009 \\
\hline B & Fishing & \\
\hline 1 & Quality of fisheries products & MMAFD Number 45 of 2014 \\
\hline 2 & Quality assurance and food security & MMAFD Number 52A/KEPMEN-KP/2013 \\
\hline 3 & $\begin{array}{l}\text { Fishing licenses } \\
\text { Illegal fishing monitoring } \\
\text { Fishing port management }\end{array}$ & Law number 45 of 2009 (fisheries) \\
\hline $\mathrm{C}$ & Port & \\
\hline 1 & Fishing port facilities & MMAFD Number PER.08/MEN/2012 \\
\hline 2 & Fishing port management and services & Law number 45 of 2009 (fisheries) \\
\hline 3 & $\begin{array}{l}\text { Fishing port equipment, health, security and } \\
\text { safety }\end{array}$ & Minister of Health Decree Number 44/2014 \\
\hline
\end{tabular}

Source: Analysis result (2018)

\section{Preparation of the model and assessment}

The inventoried regulations preparation based on the ecology, fishing, and port indicators, assessment based on applicable regulations and compliance with specified requirements. This model compiles in the form of simple application tools with formulas, so the results of the assessment will automatically be known after the form provided fully fill.

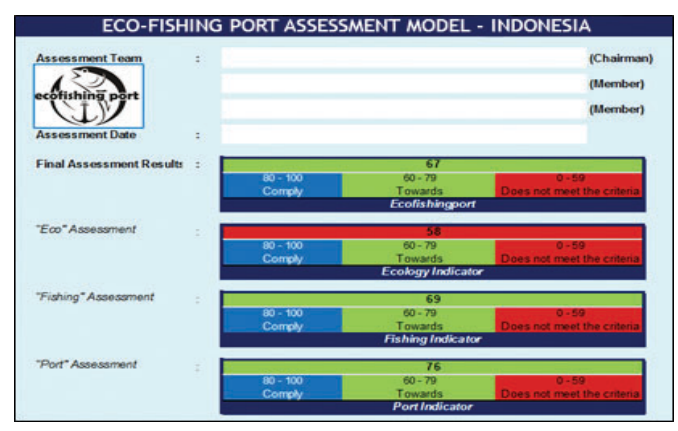

Fig. 1. Eco-fishing port assessment model

C. PPP Pondokdadap's Eco-fishing port Assessment

From the analysis results of applying eco-fishing port assessment model in PPP Pondokdadap (Table IV) obtained value 67 , which means the condition of fishing port management in PPP Pondokdadap included in the categories "towards" eco-fishing port implementation. The 
non-fulfillment of eco-fishing port standard is in $P P P$ Pondokdadap, due to non-fulfillment of the requirements on the applicable regulations. The existence of a mismatch between the implementation of the regulations and the policies and activities carried out also causes the incorrect port environmental management [19].
TABLE IV

THE RESUlTS OF THE ECO-FISHING PORT ASSESSMENT ON PPP PONDOKDADAP

\begin{tabular}{cclcc}
\hline \multicolumn{2}{c}{ Assessment result } & \multicolumn{2}{c}{ Eco-fishing port assessment } \\
\cline { 1 - 2 } Total & 67 & \multicolumn{2}{c}{ standard } \\
\cline { 1 - 3 } Eco-indicator & 58 & & Comply & $80-100$ \\
\hline Fishing indicator & 69 & Towards & $60-79$ \\
\hline Port indicator & 76 & $\begin{array}{l}\text { Doesn't meet the } \\
\text { criteria }\end{array}$ & $0-59$ \\
\hline Source: Analysis result (2018) &
\end{tabular}

Discussion about the value of eco-fishing port assessment at PPP Pondokdadap on all indicators is seen in Table V.

TABLE V

DISCUSSION OF PPP PONDOKDADAP's ECO-FISHING PORT ASSESSMENT

\begin{tabular}{|c|c|c|c|}
\hline No & Indicator & Cause activity & Information \\
\hline A & Eco & & \\
\hline 1 & $\begin{array}{l}\text { Ship waste } \\
\text { management }\end{array}$ & Ship waste pollution into sea water & $\begin{array}{l}\text { Minister of Environmental Decree Number } \\
05 \text { of } 2009\end{array}$ \\
\hline 2 & $\begin{array}{l}\text { Wastewater treatment } \\
\text { monitoring }\end{array}$ & Wastewater treatment not operated & Law Number 32 of 2009 \\
\hline 3 & $\begin{array}{l}\text { Water quality } \\
\text { monitoring }\end{array}$ & Are not done & $\begin{array}{l}\text { Minister of Environmental Decree Number } \\
115 \text { of } 2003 \\
\text { Minister of Environmental Decree Number } \\
51 \text { of } 2004\end{array}$ \\
\hline 4 & Air quality monitoring & Are not done & $\begin{array}{l}\text { Minister of Environmental Decree Number } \\
\text { KEP-45/MENLH/10/1997 } \\
\text { Bappedal Decree Number KEP-107/ } \\
\text { KABAPEDAL/11/1997 }\end{array}$ \\
\hline B & Fishing & & \\
\hline 1 & Vessels & Uncompleted requirements & $\begin{array}{l}\text { Minister of Marine and Fisheries Decree } \\
\text { Number } 52 \mathrm{~A} / \mathrm{KEPMEN}-\mathrm{KP} / 2013\end{array}$ \\
\hline 2 & $\begin{array}{l}\text { Handling, storage, and } \\
\text { fishing processing }\end{array}$ & Uncompleted requirements & $\begin{array}{l}\text { Minister of Marine and Fisheries Decree } \\
\text { Number 52A/ KEPMEN-KP/2013 }\end{array}$ \\
\hline 3 & $\begin{array}{l}\text { Fishing tools and } \\
\text { distribution }\end{array}$ & Uncompleted requirements & $\begin{array}{l}\text { Minister of Marine and Fisheries Decree } \\
\text { Number 52A/ KEPMEN-KP/2013 }\end{array}$ \\
\hline 4 & $\begin{array}{l}\text { Fish auction condition } \\
\text { and operation }\end{array}$ & Uncompleted requirements & $\begin{array}{l}\text { Minister of Marine and Fisheries Decree } \\
\text { Number 52A/ KEPMEN-KP/2013 }\end{array}$ \\
\hline $\mathrm{C}$ & Port & & \\
\hline 1 & Garbage management & $\begin{array}{l}\text { No temporary dump site, Lack of garbage } \\
\text { management facilities, Irregular schedule } \\
\text { of garbage management, No Reuse Reduce, } \\
\text { Recycle activity }\end{array}$ & $\begin{array}{l}\text { Minister of Health Decree Number } 44 \text { of } \\
2014\end{array}$ \\
\hline 2 & $\begin{array}{l}\text { Monitoring of food } \\
\text { producing }\end{array}$ & Are not done & Minister of Health Decree No. 44 of 2014 \\
\hline 3 & $\begin{array}{l}\text { Facilities of health and } \\
\text { safety }\end{array}$ & Lack of facilities & Minister of Health Decree No. 44 of 2014 \\
\hline 4 & Restroom condition & Inadequate & Minister of Health Decree No. 44 of 2014 \\
\hline 5 & Drainage & Inadequate and separate & Minister of Health Decree No. 44 of 2014 \\
\hline 6 & $\begin{array}{l}\text { Health and safety } \\
\text { socialization }\end{array}$ & Are not done & Minister of Health Decree No. 44 of 2014 \\
\hline 7 & Health and safety & Inadequate and not fulfill the requirements & Minister of Health Decree No. 44 of 2014 \\
\hline 8 & Security & $\begin{array}{l}\text { CCTV is not operated Inadequate security } \\
\text { operation }\end{array}$ & Minister of Health Decree No. 44 of 2014 \\
\hline
\end{tabular}

Source: Analysis result (2018)

\section{Environmental priorities of the fishing port}

Based on the results of significant environmental aspect analysis and eco-fishing port assessment in Pondokdadap, it is found that the order of environmental aspects should be a priority in port management (Table VI). These results compare with the European Sea Ports Organization's environmental priorities to decide whether environmental sustainability is the same. 
TABLE VI

COMPARISON OF ENVIRONMENTAL PRIORITIES OF FISHING PORT WITH ESPO

\begin{tabular}{|c|c|c|c|}
\hline No & $\begin{array}{c}1996 \\
\text { ESPO }\end{array}$ & $\begin{array}{c}2017 \\
\text { ESPO }\end{array}$ & $\begin{array}{c}2018 \\
\text { Fishing port }\end{array}$ \\
\hline 1 & $\begin{array}{l}\text { Marine side } \\
\text { development }\end{array}$ & Air quality & Garbage \\
\hline 2 & Water quality & $\begin{array}{l}\text { Energy } \\
\text { consumption }\end{array}$ & $\begin{array}{l}\text { Employment } \\
\text { absorption }\end{array}$ \\
\hline 3 & $\begin{array}{l}\text { Dredging } \\
\text { waste }\end{array}$ & Noise & Water pollution \\
\hline 4 & $\begin{array}{l}\text { Dredging } \\
\text { operation }\end{array}$ & Water quality & $\begin{array}{l}\text { Ship waste } \\
\text { production }\end{array}$ \\
\hline 5 & Dust & $\begin{array}{l}\text { Dredging } \\
\text { operation }\end{array}$ & $\begin{array}{l}\text { Liquid waste } \\
\text { production }\end{array}$ \\
\hline 6 & $\begin{array}{l}\text { Terrestrial } \\
\text { side } \\
\text { development }\end{array}$ & Garbage & $\begin{array}{l}\text { Marine } \\
\text { ecosystem } \\
\text { degradation }\end{array}$ \\
\hline 7 & $\begin{array}{l}\text { Land } \\
\text { pollution }\end{array}$ & $\begin{array}{l}\text { Terrestrial } \\
\text { side } \\
\text { development }\end{array}$ & Air pollution \\
\hline 8 & $\begin{array}{l}\text { Loss of } \\
\text { habitat }\end{array}$ & $\begin{array}{l}\text { Social } \\
\text { interaction }\end{array}$ & Sediment \\
\hline 9 & $\begin{array}{l}\text { Traffic } \\
\text { volume }\end{array}$ & Ship waste & $\begin{array}{l}\text { Energy } \\
\text { consumption }\end{array}$ \\
\hline 10 & $\begin{array}{l}\text { Industrial } \\
\text { waste }\end{array}$ & $\begin{array}{l}\text { Climate } \\
\text { change }\end{array}$ & Noise \\
\hline
\end{tabular}

Source: Analysis result (2018) and ecoports foundation (2017)

The environmental priority of fishing port at $P P P$ Pondokdadap in 2018 has some similarities to the priorities of ports in Europe by 2017 and only 1 priority in 1996 [20]. However, it differs in the priority and priority sequences of employment absorption that exist only in fishing ports. This happens because, at fishing port, fishing activity is affected by the natural reason, that is a fish season. At the time of not the fish season, there will be a drastic decrease in employment and activities that occur in the port.

E Fishing port environmental management index

From the eco-fishing port assessment model known as the environmental management indicators that figure fishing port management position that compliance with eco-fishing port standards. This indicator is a reference for evaluating fishing ports management by the government. In addition, this indicator is used for assessment of the fishing port environmental management index (FEMI) which conducts annually by the government. This FEMI will show whether the government's performance in managing the port is proenvironment or not and the increase/decrease of environmental management performance monitoring every year.

TABLE VII

\begin{tabular}{clcc} 
PPP PONDOKDADAP's ENVIRONMENTAL MANAGEMENT INDEX \\
\cline { 2 - 3 } $\begin{array}{l}\text { Fishing Port Environmental } \\
\text { Management Indicator } \\
\text { (FEMI) }\end{array}$ & Categories & $\begin{array}{c}\text { percentage } \\
\text { of } \\
\text { deployment }\end{array}$ \\
\hline $\mathrm{A}$ & $\begin{array}{l}\text { Certification of an } \\
\text { environmental } \\
\text { management system }\end{array}$ & Eco & 0 \\
\hline $\mathrm{B} \quad$ & $\begin{array}{l}\text { Monitoring of } \\
\text { Significant } \\
\text { Environmental Aspects }\end{array}$ & Eco & 100 \\
\hline $\mathrm{C}$ & $\begin{array}{l}\text { Completeness of Port } \\
\text { Facility }\end{array}$ & Port & 87 \\
\hline $\mathrm{D}$ & $\begin{array}{l}\text { Port Management and } \\
\text { Services }\end{array}$ & Port & 100 \\
\hline
\end{tabular}

\begin{tabular}{|c|c|c|c|}
\hline \multicolumn{2}{|r|}{$\begin{array}{l}\text { Fishing Port Environmental } \\
\text { Management Indicator } \\
\text { (FEMI) }\end{array}$} & Categories & $\begin{array}{l}\text { percentage } \\
\text { of } \\
\text { deployment }\end{array}$ \\
\hline $\mathrm{E}$ & $\begin{array}{l}\text { Environmental } \\
\text { Management Documents }\end{array}$ & Eco & 90 \\
\hline $\mathrm{F}$ & $\begin{array}{l}\text { Fishing port } \\
\text { Environmental Quality } \\
\text { Monitoring }\end{array}$ & Eco & 54 \\
\hline G & $\begin{array}{l}\text { Management of Fishing } \\
\text { Ports } \\
\text { (Hygiene, Health, } \\
\text { Safety, Security, Order) }\end{array}$ & Port & 58 \\
\hline $\mathrm{H}$ & $\begin{array}{l}\text { Quality Assurance and } \\
\text { Safety of Fishery } \\
\text { Products }\end{array}$ & Fishing & 54 \\
\hline I & $\begin{array}{l}\text { Monitoring of Illegal } \\
\text { Fishing }\end{array}$ & Fishing & 83 \\
\hline $\mathrm{J}$ & Environmental audit & Eco & 0 \\
\hline
\end{tabular}

$\mathrm{FEMI}=A x 1.5+B x 1+C x 0.75+D x 0.75+E x 1+F x 1.25+$ $G x 1+H x 1+I x 1+J x 0.75$

The calculation results of PPP Pondokdadap Fishing Port Environment Management Index (FEMI) in 2018 are:

FEMI $=0 \times 1.5+100 \times 1+87 \times 0.75+100 \times 0.75+90 \times 1+$

$54 x 1.25+58 \times 1+54 \times 1+83 \times 1+\quad 0 \times 0.75$

$\mathrm{FEMI}=5.93$

From PPP Pondokdadap's FEMI calculation, the value in 2018 is 5.93, but the improvement of environmental performance will be known in the next index assessment (2019, etc.). This is because the new FEMI is compiled and implemented in 2018 so that evaluation cannot be done. To provide an overview of the conditions of the environmental management index, the FEMI value of the PPP Pondokdadap compare with the average value of the environmental management index of 91 ports in Europe from the compliance of its environmental management indicators (Table VIII). With the analysis of the increase of the index value of $(1.15-0.36) /$ year, if continuous improvement of environmental management indicator is done then, predicted of Pondokdadap FEMI value achievement above 7 will be achieved within 5 years.

TABLE VIII

COMPARISON ENVIRONMENTAL MANAGEMENT INDEX OF PORTS IN EUROPE AND PPP PONDOKDADAP

\begin{tabular}{lcccc}
\hline Environmental & \multicolumn{3}{c}{ ESPO } & Pondokdadap \\
\cline { 2 - 5 } Management & 2013 & 2016 & 2017 & 2018 \\
\cline { 2 - 5 } Index Value & 7,25 & 7,72 & 8,08 & 5,93 \\
\hline Percentage & - & 6,48 & 4,66 & - \\
increase & & & & \\
from the \\
previous \\
$\quad$ \\
$\quad$
\end{tabular}

\section{CONCLUSION}

Fishing ports are ports that have special characteristics related to commodities and their activities. Therefore, an environmentally management of fishing port requires a specific model in its implementation. This research resulted in eco-fishing port assessment model prepared based on the regulations applicable in Indonesia with reference to ISO 14001. With ecological indicators, fishing and ports can 
represent the characteristics of different between fishing ports with public ports. From the eco-fishing port assessment model that applies to PPP Pondokdadap knowing port management categories is (towards) ecofishing port. This means that port managers are still improving the port environmental management system to comply with eco-fishing port standards and improving compliance with the prevailing regulations in Indonesia. Through the eco-fishing port model are also obtained an index of fishing port environmental management (FEMI) that can use to check and evaluate port environmental management performance development. According to the research result, the eco-fishing port assessment model can use as a tool for environmental management on fishing ports in Indonesia.

\section{REFERENCES}

[1] Marine and Fisheries Ministry Decree Number PER.08/MEN/2012. Jakarta, 2012.

[2] WWF Indonesia, "Bahu-Membahu Menuju Perikanan yang Berkelanjutan di Sendang Biru," 2014. Melalui http://www.wwf. or.id/ berita fakta/ ?35202 /bahu-membahu-menuju-perikanan-yangberkelanjutan-di-sendang-biru .(27/09/2017)

[3] J.M. Mahendra, B. Wiryawan, and D. Simbolon, "Analisis Tingkat Pemanfaatan Sumberdaya Ikan Tuna dengan Metode Spawning Potential Ratio di Perairan Sendangbiru," Jurnal Ilmu dan Teknologi Kelautan Tropis, 9(2), 597-604, 2017.

[4] R. B. A. Nugraha, L. O. N. Mbay, and J. Kusyanto, "Penerapan Konsep Fishing Ecoport untuk Pengembangan Pelabuhan Perikanan di Indonesia,".Jurnal Kelautan Nasional, 9(3), 163-169, 2014.

[5] Saikudin, H. Sulistio dan A. Wicaksono, "Kajian Kinerja Angkutan Barang di Pelabuhan Tanjung Tembaga Kota Probolinggo," Jurnal Rekayasa Sipil, 8(3), 181-191. 2014.

[6] Supriyanto, "Analisis Pengelolaan Pelabuhan Perikanan Berwawasan Lingkungan di Pelabuhan Perikanan Samudera Nizam Zachman Jakarta," Jurnal Ilmu Lingkungan, 7, 159-179, 2013.
[7] J.S.L. Lam and T. Notteboom, "The greening of ports: a comparison of port management tools used by leading ports in Asia and Europe," Transport Reviews, 34(2), 169-189, 2014.

[8] J. Dinwoodie, S. Tuck, H. Knowles, J. Benhin, and M. Sansom, "Sustainable Development of Maritime Operations in Ports," Business Strategy and the Environment, 21, 111-126, 2012.

[9] Q. L. Xuan, H.V. Van, L. Hens, and B. V. Heur, "Stakeholder Perceptions and Involvement in the Implementation of the Environmental Management System in ports in Vietnam and Cambodia," Journal of Cleaner Production, 64, 173-183, 2014.

[10] M. Puig, C. Wooldridge, J. Casal, and R.M. Darbra, "Tool for the Identification and Assessment of Environmental Aspects in Ports (TEAP)," Ocean \& Coastal Management, 113, 8-17, 2015.

[11] M. Puig, C. Wooldridge, and R. M. Darbra, "Identification and Selection of Environmental Performance Indicators for Sustainable Port Development," Marine Pollution Bulletin, 81, 124-130, 2014.

[12] M. Puig, A. Michail, C. Wooldridge, and R.M. Darbra, "Benchmark Dynamics in the Environmental Performance of Ports," Marine Pollution Bulletin. 121, 111-119, 2017.

[13] European Commission, 2015. https://ec.europa.eu/europeaid/blending/eco-fishing-portsdevelopment-pilot-project_en. Eco fishing ports development pilot project. (16 May 2018)

[14] European Sea Ports Organisation (ESPO), "Green Guides," Brussel, 2012.

[15] SNI 19-14001-2005, "Sistem manajemen lingkungan - Persyaratan dan panduan penggunaan," Jakarta: Badan Standardisasi Nasional, 2005.

[16] V. Tatar, "Environmental Management Systems for Port Areas," The Online Journal of Science and Technology, 7(3), 41-47, 2017.

[17] A.J. Edwards, ISO 14001, "Environmental Certification Step by Step," Elsevier Butterworth-Heinemann. Burlington, England, 2004.

[18] Directorate General of Capture Fisheries Ministry of Marine Affairs and Fisheries, "Decision of Director General of Capture Fisheries Number 62 A/KEP-DJPT/2015on the Strategic Plan of the Directorate General of Capture Fisheries 2015-2019"' Jakarta, 2015.

[19] H. Tjenne, Soemarno, B. Yanuwiadi, and B.P. Iskandar, "Community-based Waste Management in Makassar: Formulation of Priority Policy with Analytical Hierarchy Process," Australian Journal of Basic And Applied Sciences, 11(10), 155-160, 2017.

[20] ESPO, Sustainability Report, 2017.

[21] Ecoports Foundation, 2017. 